\title{
Role of dietary sulphate in the regulation of methanogenesis in the human large intestine
}

\author{
S U Christl, G R Gibson, J H Cummings
}

\begin{abstract}
Hydrogen produced during colonic fermentation may be excreted, or removed by $\mathbf{H}_{2}$ consuming bacteria such as methanogenic and sulphate reducing bacteria. In vitro, sulphate reducing bacteria compete with methanogenic bacteria for hydrogen when sulphate is present. In this study the hypothesis that sulphate in the diet could alter $\mathbf{C H}_{4}$ production in vivo has been tested. Six methane excreting volunteers were fed a low sulphate diet $(1.6$ $\mathrm{mmol} / \mathrm{d}$ ) for 34 days with the addition of 15 mmol sodium sulphate from days 11-20. Breath methane was measured and viable counts and metabolic activities of methanogenic bacteria and sulphate reducing bacteria determined in faeces. Whole gut transit time and daily stool weight were also measured. When sulphate was added to the diet, breath methane excretion decreased in three of the subjects while faecal sulphate reduction rates rose from $7.5(0.5)$ to $20.3(4.3) \mathrm{nmol} \mathrm{SO}_{4}$ reduced/h/g faeces. Sulphate reducing bacteria, which were not detected during the control diet, were found and viable counts of methanogenic bacteria fell from $10^{7}-10^{9} / \mathrm{g}$ faeces to $10^{6} / \mathrm{g}$. Methanogenic counts and breath $\mathrm{CH}_{4}$ recovered after sulphate addition was stopped. No change was found in the other three subjects. Faecal weights and transit times were not different between study periods. It is concluded that methanogenesis is regulated by dietary sulphate if sulphate reducing bacteria are present. Dietary sulphate may allow growth of sulphate reducing bacteria which inhibit the growth of methanogenic bacteria. This may explain the absence of $\mathrm{CH}_{4}$ in the breath of many people in western populations.
\end{abstract}

(Gut 1992; 33: 1234-1238)

The large intestine salvages energy from dietary residues and endogenous organic matter not absorbed in the small intestine, through fermentation by colonic bacteria. ${ }^{\prime}$ This process generates short chain fatty acids which are absorbed, and hydrogen and carbon dioxide. Most people extrete hydrogen in breath and flatus but in $30-50 \%$ of western populations and in $80-90 \%$ of rural black Africans, methane $\left(\mathrm{CH}_{4}\right)$ is also excreted..$^{2-5} \mathrm{CH}_{4}$ is produced by reduction of $\mathrm{CO}_{2}$ with $\mathrm{H}_{2}$ by methanogenic bacteria and epidemiological studies show that the carriage of these bacteria is determined in early childhood. No dietary factors have been shown to affect colonisation of the large intestine with methanogens. ${ }^{67}$

Molecular hydrogen is produced by oxidation of $\mathrm{NADH}_{2}$ and $\mathrm{FADH}_{2}$ generated during bacterial glycolysis. High partial pressures of $\mathrm{H}_{2}$, however, slow bacterial hexose breakdown by impairing regeneration of NAD. ${ }^{89}$ Energy efficient anaerobic ecosystems therefore usually have $\mathrm{H}_{2}$ consuming organisms. In the rumen, $\mathrm{H}_{2}$ is consumed by methanogenic bacteria ${ }^{8}$ and similarly, in methanogenic human subjects, $75 \%$ of the hydrogen excreted is as methane. ${ }^{10}$ In nonmethanogenic subjects, sulphate reducing bacteria consume some of the hydrogen produced in fermentation. ${ }^{11}$ In vitro data show that sulphate reducing bacteria outcompete methanogens for $\mathrm{H}_{2}$ but only if sufficient sulphate is available. ${ }^{12}$

Sulphate availability may therefore be important in determining methanogenesis in man. Sulphate concentration in the colon is largely dependent on dietary intake. ${ }^{13}$ Changes in dietary sulphate could alter the activity of sulphate reducing bacteria and thus affect methanogenesis in the colon. To test this hypothesis, six methanogenic subjects have been fed a low sulphate diet for 34 days supplemented with sodium sulphate from day 11 to 20 . Breath methane was monitored and metabolic activities of methanogenic bacteria and sulphate reducing bacteria studied in faecal samples.

\section{Methods}

\section{SUBJECTS}

Six healthy subjects (two men, four women, age 26-61 years) who had no history of gastrointestinal disease or use of antibiotics for at least three months took part in the study. All excreted methane in their breath at least $5 \mathrm{ppm}$ above background.

\section{STUDY DESIGN}

The study was conducted in the metabolic suite of the MRC Dunn Clinical Nutrition Centre, Cambridge. The subjects were fed a controlled low sulphate diet for 34 consecutive days. From day 11 to day $20,15 \mathrm{mmol}$ sodium sulphate was

TABLE I Mean breath $\mathrm{CH}_{4}(\mathrm{~A})$ and $\mathrm{H}_{2}(B)$ concentrations, ppm (SEM) during the last three days with basal diet and with 15 mol sodium sulphate added in responders $(n=3)$ and nonresponders $(n=3)$

\begin{tabular}{|c|c|c|c|}
\hline & Basal diet & High sulphate & Basal diet \\
\hline $\begin{array}{l}\text { A: } \\
\text { Responders } \\
\text { Non-responders } \\
\text { B: }\end{array}$ & $\begin{array}{l}22 \cdot 2(7 \cdot 2)^{\star} \\
21 \cdot 6(4 \cdot 1)\end{array}$ & $\begin{array}{l}1 \cdot 5(0 \cdot 2)^{\star} \\
22 \cdot 7(7 \cdot 5)\end{array}$ & $\begin{array}{l}17 \cdot 0(4 \cdot 1) \\
21 \cdot 0(7 \cdot 2)\end{array}$ \\
\hline $\begin{array}{l}\text { Responders } \\
\text { Non-responders }\end{array}$ & $\begin{array}{l}14 \cdot 7(5 \cdot 8) \\
25 \cdot 5(6 \cdot 5)\end{array}$ & $\begin{array}{l}19 \cdot 7(9 \cdot 8) \\
19 \cdot 9(6 \cdot 2)\end{array}$ & $\begin{array}{l}16 \cdot 0(4 \cdot 5) \\
21 \cdot 4(7 \cdot 9)\end{array}$ \\
\hline
\end{tabular}

*Significant difference $(p<0.025)$ between basal diet and high sulphate. 
added to the diet. End expiratory breath samples were collected three times daily throughout the study and analysed for hydrogen and methane concentration. On days 10,20 , and 34 , a faecal sample was collected for measurement of bacterial counts and metabolic activity. Transit times were determined using a multiple dose marker technique. Informed consent was obtained and the study protocol was approved by the ethical committee of the MRC Dunn Nutrition Unit.

DIET

The diets were prepared in the metabolic kitchen of the unit. They consisted of three different, nutritionally balanced menus which were served in a three day rotation. Average nutrient composition (\% energy) was protein, 15\%; carbohydrate, $55 \%$; and fat, $29 \%$. The sulphate content of this diet has previously been measured at $1 \cdot 7$ $\mathrm{mmol} /$ day. ${ }^{13}$ The subjects were allowed to drink tea and coffee, prepared with deionised water ad libitum. From day 11 to 20 a dose of $5 \mathrm{mmol}$ sodium sulphate in gelatin capsules, was given with each main meal ( $15 \mathrm{mmol} / \mathrm{day})$.

\section{GAS MEASUREMENTS}

End expiratory breath samples were collected in duplicate every day at $800 \mathrm{am}, 300 \mathrm{pm}$, and $1000 \mathrm{pm}$ using a collapsible tube with an open end as previously described. ${ }^{14}$ Hydrogen concentrations were measured on a GMI Exhaled Hydrogen Monitor (GMI Medical Ltd, Ren-

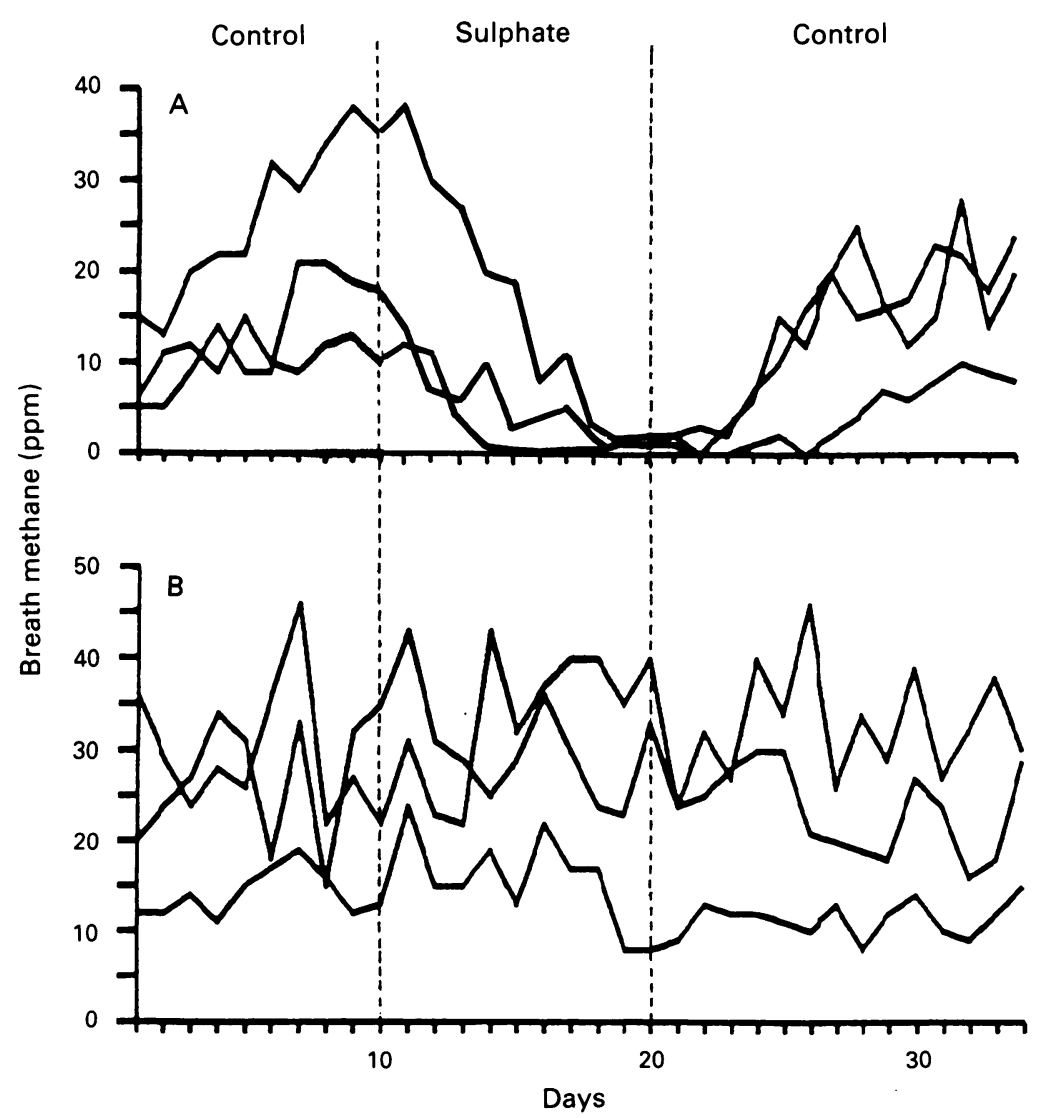

Figure 1: Breath methane concentrations (mean of three duplicate measurements daily) in responders $(A, n=3)$ and non-responders $(B, n=3)$ with basal diet and with the addition of 15 mmol sodium sulphate per day. frew, Scotland), and methane by gaschromatography (PYE 104, PYE-Unicam, Cambridge, England) using flame ionisation and a $2 \mathrm{~m} \times$ $4 \mathrm{~mm}$ glass column packed with Poropak Q. Oven temperature was $50^{\circ} \mathrm{C}$ and the detector $100^{\circ} \mathrm{C}$, with nitrogen as carrier gas. Methane concentrations were calculated as the difference between breath and a corresponding room air sample.

\section{BACTERIAL COUNTS}

Viable counts of methanogenic bacteria were enumerated using the Hungate roll tube technique. ${ }^{15}$ For enumeration of viable sulphate reducing bacteria the agar shake dilution method of Widdel et $a l^{16}$ was used with media and conditions of cultivation as described by Gibson et al. "The dilutions used give a detection limit of $10^{2}$ viable counts per gram faeces for both methanogenic bacteria and sulphate reducing bacteria.

\section{MICROBIAL ACTIVITY}

Faecal slurries were prepared by diluting the stool samples in anaerobic sodium phosphate buffer $(0 \cdot 1 \mathrm{~mol} / 1, \mathrm{pH} 7 \cdot 0)$ to a final concentration of $5 \%(\mathrm{w} / \mathrm{v})$. Lintners starch was added to a slurry portion of $60 \mathrm{ml}$ in a serum bottle $(70 \mathrm{ml}$ capacity) to give a final concentration of $0.2 \%$ $(\mathrm{w} / \mathrm{v})$. The bottles were gassed out with argon and then incubated for 48 hours at $37^{\circ} \mathrm{C}$ on an orbital shaker. Hydrogen, methane and carbon dioxide production in the head space gas were measured by gas chromatography as described by Allison $e t a l^{17}$ and hydrogen sulphide was determined using a colorimetric method after precipitation of $\mathrm{S}^{2-}$ in $10 \%$ zinc acetate. ${ }^{18}$ For determination of sulphate reduction rates the ${ }^{35} \mathrm{~S}_{-} \mathrm{SO}_{4}$ core injection and distillation method of Jorgensen ${ }^{19}$ was used (incubation time 18 hours).

\section{GASTROINTESTINAL TRANSIT TIME}

Transit times were measured once on the basal diet and once during sulphate feeding. A modified version of the method described by Cummings et $a l^{20}$ was used. On four consecutive days at 800 am 20 radiopaque plastic shapes, packed in gelatine capsules, were given orally. The particles were distinctly shaped, and a different set was used for each day. All faeces were collected, the times recorded, and the markers determined by radiography. Transit time was calculated as the average passage time of all markers recovered.

\section{STATISTICAL ANALYSIS}

Variations are expressed as standard error of the mean. Analysis for significance were done using Student's $t$ test for paired samples and the two group $t$ test for unpaired samples.

\section{Results}

Mean daily $\mathrm{CH}_{4}$ concentrations in breath for 
each subject throughout the study are shown in Figure 1. In three of the six subjects (responders) methane excretion showed a pronounced fall a few days after $\mathrm{SO}_{4}$ was added to the diet, so that by 10 days with added sulphate methane concentration was less than $2 \mathrm{ppm}$ in all samples measured in these three subjects. By seven days after returning to the low sulphate diet, breath $\mathrm{CH}_{4}$ concentrations had increased again and returned almost to control levels by the end of the study. In the other three subjects (nonresponders), methane excretion was not significantly affected by the sulphate supplement (Fig 1). The average breath $\mathrm{CH}_{4}$ concentrations during the last three days of each test period were calculated for responders and non-responders separately (Table I).

\section{BREATH HYDROGEN}

Table I shows mean breath hydrogen concentrations for the last three days of each test period for

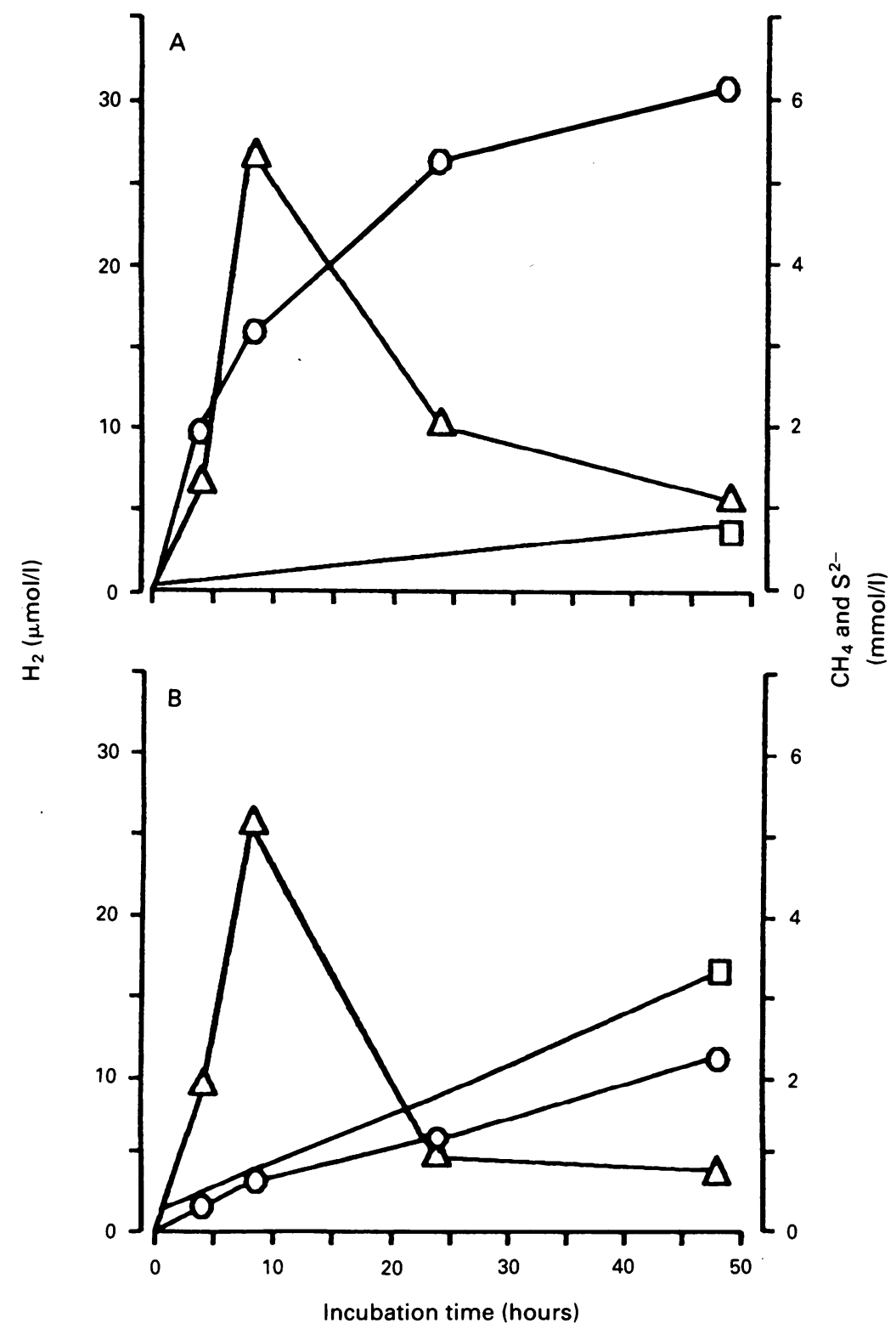

Figure 2: Pattern of hydrogen production and consumption in a faecal slurry incubation of a responder. (A) with basal diet. $(B)$ with $15 \mathrm{mmol}$ sodium sulphate per day added to the diet. $\triangle \mathrm{H}_{2}, \square \mathrm{S}^{2-}, \mathrm{O} \mathrm{CH}_{4}$. responders and non-responders. There was no effect of the low sulphate and high sulphate diets.

\section{BOWEL HABIT}

When all subjects were taken together there were no differences in mean transit time, faecal weight, and faecal $\mathrm{pH}$ between the control diet and the sulphate supplemented diet (Table II). In the three responders, initial faecal weight was higher, transit time was shorter, and $\mathrm{pH}$ was lower than in non-responders. Both the basal diet and the sulphate supplement were well tolerated by all the volunteers and no gastrointestinal symptoms were reported.

BACTERIAL COUNTS AND MICROBIAL ACTIVITY Typical gas production data from a faecal slurry of one responder is shown in Figure 2. During the low sulphate period, there was active methanogenesis and little production of sulphide. The latter increased markedly, however, when sulphate was added to the diet, while methanogenesis became suppressed by approximately $60 \%$. The complete data are shown in Table III. In responders, viable counts of methanogenic bacteria decreased in the presence of extra sulphate in the diet while sulphate reducing bacteria were detected in low numbers. Sulphate reducing activity and sulphide production rates in faecal slurries were significantly higher during the high sulphate period compared with the control diet (Table III). Counts and metabolic parameters reverted to approximately pre- $\mathrm{SO}_{4}$ levels when sulphate was stopped. Non-responders had lower $\mathrm{SO}_{4}$ reduction rates on the control diet than responders. In these subjects, there was no difference in methanogenic counts and activities remained stable in the presence or absence of $15 \mathrm{mmol} / \mathrm{d}$ sulphate. Viable counts of sulphate reducing bacteria were never found above the detection limit of $10^{2} / \mathrm{g}$ faeces in non-responders (Table III).

\section{Discussion}

In this study, the addition to the diet of $15 \mathrm{mmol}$ sodium sulphate/day over a 10 day period inhibited methane production in three of six normally methanogenic subjects. As methanogenesis was reduced signs of sulphate reduction, previously absent during the control diet, became apparent in faeces of these subjects. When the supply of sulphate was stopped, methane production returned. This experiment shows a previously unknown dietary effect upon bacterial activity in the human colon.

Methane gas is regarded as a harmless byproduct of fermentation in the large intestine of man. $\mathrm{CH}_{4}$ production is thought to be fairly constant in individuals and to be independent of diet. ${ }^{7}$ The reasons why western populations separate into methane producers and nonproducers has never been explained. In recent studies, however, we have shown that methane production is more important than previously believed. Quantitative measurements show that in methanogenic subjects the majority of gaseous 
hydrogen produced from fermentation is consumed by methanogenic bacteria. ${ }^{10}$

During fermentation, hydrogen gas production is used by bacteria to allow oxidation of reduced cofactors $\left(\mathrm{NADH}_{2} \rightarrow \mathrm{NAD}+\mathrm{H}_{2}\right) . \mathrm{H}_{2}$ must be rapidly removed from the fermentation system, however, because high partial pressures of $\mathrm{H}_{2}$ inhibit the reactivation of these coenzymes which are essential in glycolysis. ${ }^{9}$ Reduction of $\mathrm{CO}_{2}$ by $\mathrm{H}_{2}$ to $\mathrm{CH}_{4}$ by methanogenic bacteria is an effective way of lowering $\mathrm{H}_{2}$ levels and allows bacteria to generate more oxidised products which result in higher energy yields. ${ }^{8}$ In the absence of methanogenesis, large intestinal fermentation is inefficient and produces different organic end products unless an alternative pathway exists to dispose of reducing equivalents. $^{21} 22$

In previous studies we have shown that in the colon of non-methanogenic human subjects, significant populations of sulphate reducing bacteria exist. " These bacteria use molecular hydrogen as well as other electron donors, for the dissimilatory reduction of sulphate to sulphide. In marine sediments and faeces, sulphate reducing bacteria outcompete methanogenic bacteria because of their higher affinity for such substrates. ${ }^{12324}$ Methanogenic bacteria tend to predominate in a sulphate depleted environment, however. ${ }^{25}$ The present study provides further evidence for these interactions in the colon.

Under stable dietary conditions, western populations may be separated into predominantly methanogenic or sulphate reducing subjects. ${ }^{11}$ A proportion of $\mathrm{CH}_{4}$ producers (three of six in this study), however, may also harbour small numbers of sulphate reducing bacteria (not detectable with the methods used in this study). The presence of these bacteria was shown by higher sulphate reduction rates recorded in faeces of these subjects (responders) even on the basal diet. When sulphate availability is increased sulphate reducing bacteria proliferate and eventually may outcompete methanogens when the sulphate supply is sufficient. This is supported by our observation that sulphate reduction rates and sulphide production in faeces of the three responders increased when sulphate was supplemented to the diet, while methanogenesis became substantially reduced. Correspondingly, sulphate reducing bacteria which were not found during the basal diet, became detectable while counts of methanogenic bacteria decreased 100 -fold during this period.

Metabolic activity of sulphate reducing bacteria was, however, well below values usually found in non-methanogenic subjects, " and

TABLE II Faecal wet weights, gastrointestinal transit times, and faecal pH (SEM) with basal diet and with $15 \mathrm{mmol}$ sodium sulphate per day added. Differences not significant

\begin{tabular}{clcc}
\hline & & Basal diet & High sulphate \\
\hline Faecal weight & Responders & $150(12)$ & $164(16)$ \\
(g wet wt/d) & Non-responders & $99(13)$ & $112(15)$ \\
& All subjects & $125(18)$ & $138(13)$ \\
Transit time & Responders & $41 \cdot 6(4 \cdot 6)$ & $39 \cdot 1(3 \cdot 0)$ \\
(hours) & Non-responders & $62 \cdot 8(19 \cdot 5)$ & $59 \cdot 7(18 \cdot 4)$ \\
& All subjects & $52 \cdot 2(21 \cdot 3)$ & $49 \cdot 4(20 \cdot 0)$ \\
Faecal pH & Responders & $6 \cdot 9(0 \cdot 19)$ & $6 \cdot 7(0 \cdot 14)$ \\
& Non-responders & $7 \cdot 1(0 \cdot 10)$ & $6 \cdot 7(0 \cdot 20)$ \\
& All subjects & $7 \cdot 0(0 \cdot 12)$ & $6 \cdot 7(0 \cdot 16)$ \\
\hline
\end{tabular}

TABLE III Bacterial counts and microbial activity (SEM) on basal diet and with $15 \mathrm{mmol}$ sodium sulphate added, for responders $(A, n=3)$ and non-responders $(B, n=3)$

\begin{tabular}{cllll}
\hline & & Basal diet & High sulphate & Basal diet \\
\hline Sulphate reduction & A & $7 \cdot 5(0 \cdot 5)^{\star}$ & $20 \cdot 3(4 \cdot 3)^{\star}$ & $7 \cdot 6(1 \cdot 3)$ \\
rate $(\mathrm{nmol} / \mathrm{g} / \mathrm{h}) \dagger$ & B & $2 \cdot 8(1 \cdot 7)$ & $4 \cdot 4(1 \cdot 9)$ & $3 \cdot 3(1 \cdot 1)$ \\
Sulphide $\mathrm{production}$ & A & $0 \cdot 35(0 \cdot 04)^{\star}$ & $0 \cdot 99(0 \cdot 11)$ & $0 \cdot 53(0 \cdot 14)$ \\
rate $(\mu \mathrm{mol} / \mathrm{g} / \mathrm{h}) \neq$ & B & $0 \cdot 22(0 \cdot 03)$ & $0 \cdot 26(0 \cdot 04)$ & $0 \cdot 25(0 \cdot 02)$ \\
Methane $\mathrm{production}$ & A & $1 \cdot 43(0 \cdot 20)^{\star}$ & $0 \cdot 29(0 \cdot 23)^{\star}$ & $1 \cdot 73(0 \cdot 13)$ \\
rate $(\mu \mathrm{mol} / \mathrm{g} / \mathrm{h}) \ddagger$ & B & $1 \cdot 89(0 \cdot 09)$ & $1 \cdot 73(0 \cdot 07)$ & $1 \cdot 63(0 \cdot 10)$ \\
Sulphate reducing & A & 0 & $3 \cdot 3(0 \cdot 3)$ & 0 \\
bacteria $\left(\log _{10} / \mathrm{g}\right)$ & B & 0 & 0 & 0 \\
Methanogenic & A & $9 \cdot 2(0 \cdot 5)$ & $6 \cdot 3(0 \cdot 2)$ & $8 \cdot 5(0 \cdot 3)$ \\
bacteria $\left(\log _{10} / \mathrm{g}\right)$ & B & $8 \cdot 9(0 \cdot 6)$ & $9 \cdot 1(0 \cdot 5)$ & $8 \cdot 6(0 \cdot 5)$ \\
\hline
\end{tabular}

Weights are wet weights of faeces.

$\star$ Significant differences $(p<0.05)$ between basal diet and high sulphate; †Core injection method; $¥$ Slurry experiment.

viable counts of sulphate reducing bacteria were too low to explain the marked drop in methanogenesis. A reason for this may be the relatively short study period which was probably not sufficient for the bacterial population in more proximal areas of the colon to equilibrate with that measured in faeces. This may be important as a recent study ${ }^{26}$ has revealed some differences between caecal and faecal flora, an observation which may limit the conclusions made from measurements with faecal inocula. Changes in both faecal sulphate reducing activity and sulphate reducing bacteria counts during the sulphate feeding period, however, strongly suggest a relation between the metabolism of these bacteria and the changes in methanogenesis observed in this study.

Breath hydrogen excretion was not significantly different between the low sulphate and the high sulphate diets, indicating that the volume of hydrogen consumed either by methanogenic bacteria or by sulphate reducing bacteria might be similar.

In three of the six subjects, sulphate reduction rates were low and did not show any change throughout the study. Sulphate reducing bacteria were never detected, and methane excretion was not affected by sulphate feeding. Small and undetectable numbers of sulphate reducing bacteria may have been present, unable to increase rapidly enough to be detected during the short period of this study. Alternatively, sulphate may have been absorbed more completely in the small intestine of these subjects with insufficient amounts being available for colonic sulphate reduction.

It was noted that breath methane concentrations were generally higher in non-responders than in responders. This may be explained by the fact that more hydrogen was used in a metabolism other than methanogenesis in these subjects even on the basal diet. Moreover, during the basal diet breath $\mathrm{CH}_{4}$ concentrations increased in responders suggesting that their usual diet contained enough sulphate for sulphate reducing bacteria to reduce the amount of hydrogen available to methanogens, whilst on the sulphate depleted basal diet more hydrogen could be used for methanogenesis.

Intestinal transit times were measured to see whether the effect of sulphate upon methanogenesis might be the result of faster bowel transit, because the laxative properties of sodium 
sulphate are recognised. The amount used in this study given in three doses, however, is small compared with the usual laxative dose of about $60 \mathrm{mmol}$. Transit times were not different between the control period and the period with $\mathrm{SO}_{4}$ supplementation.

The sulphate content of an average United Kingdom diet is about $5 \mathrm{mmol} / \mathrm{d} .{ }^{1327}$ It has been shown that during intakes of up to $5 \mathrm{mmol} / \mathrm{d}$ most of the sulphate is absorbed in the small intestine and very little is found in ileal effluent ${ }^{13}$ although endogenous sources such as mucopolysaccharides provide an unknown additional amount of sulphate. ${ }^{28}$ This is probably not enough to allow significant dissimilatory sulphate reduction. At intakes greater than $5 \mathrm{mmol} / \mathrm{d}$, however, a greater proportion is delivered to the colon. Recent studies of sulphate absorption in man indicate that on a diet of 16.6 $\mathrm{mmol} / \mathrm{d}$ about $12 \mathrm{mmol}$ would be expected to reach the colon. ${ }^{13}$

During the bacterial reduction of one mole of sulphate, four moles of hydrogen are consumed. Thus the reduction of $12 \mathrm{mmol} \mathrm{SO} 4$ would require a volume of $1100 \mathrm{ml} \mathrm{H}_{2}$. The average breath methane concentration in responders on the low sulphate diet was $25 \mathrm{ppm}$. If ventilation rate is estimated to be $4 \mathrm{l} / \mathrm{min}$ this is equivalent to an excretion of about $140 \mathrm{ml} / 24 \mathrm{~h}$ in breath. We have recently shown that at such an excretion rate, breath exhalation is about $50-60 \%$ of the total excretion. ${ }^{10}$ Total methane excretion can therefore be estimated at $300 \mathrm{ml} / \mathrm{d}$. Thus, about $1200 \mathrm{ml}$ of hydrogen were consumed in methanogenesis $\left(4 \mathrm{~mol} \mathrm{H}_{2} / \mathrm{mol} \mathrm{CH}_{4}\right)$ when sulphate supply was limited. This is equal to the volume assumed to be consumed by the reduction of 12 $\mathrm{mmol} \mathrm{SO}_{4}$ in the three responders. Although this balance is not entirely based on direct measurements, it shows how the observed interactions between sulphate reducing bacteria and methanogenic bacteria in vivo can be understood as competition for the mutual substrate hydrogen. When both types of bacteria are present in the large intestine, hydrogen metabolism may be regulated by the availability of sulphate in the colon. We cannot exclude the possibility, however, that other unknown mechanisms may be involved in the effects observed in this study.

Some dietary components such as bread, food preserved with sulphur dioxide, and alcoholic beverages such as beer, wine and cider are rich in sulphate. ${ }^{29-31}$ Their consumption may increase sulphate ingestion naturally to quite high amounts. Thus, the amount of sulphate given in this study can be reached by dietary means in a proportion of people.

In conclusion, we have shown evidence for regulation of methanogenesis by dietary sulphate if sulphate reducing bacteria are present in the colon. Sulphate feeding allows growth of sulphate reducing bacteria which then may inhibit methanogenic bacteria by substrate competition. This may explain the absence of methane in the breath of $40-50 \%$ of western populations.

The authors wish to thank Elaine Collard for help with the diets, and the volunteers for their cooperation. S U Christl was supported by a grant of the Deutsche Forschungsgemeinschaft, Bonn, Germany FRG.

1 Cummings JH. Fermentation in the human large intestine: evidence and implications for health. Lancet 1983; i: 1206-9.

2 McKay LF, Eastwood MA, Brydon WG. Methane excretion in man - a study of breath, flatus, and faeces. Gut 1985;26: 69-74.

3 Bjorneklett A, Jensen E. Relationships between hydrogen $\left(\mathrm{H}_{2}\right.$ and methane $\left(\mathrm{CH}_{4}\right)$ production in man. Scand Gastroenterol 1982; 17: 985-92.

4 Pitt P, De Bruijn KM, Beeching MF, Goldberg E, Blendis LM. Studies on breath methane: the effect of ethnic origin and lactulose. Gut 1980; 21: 951-9.

5 Segal I, Walker ARP, Lord S, Cummings JH. Breath methane and large bowel cancer risk in contrasting African populations. Gut 1988; 29: 608-13.

6 Peled Y, Gilat T, Liberman E, Bujanover Y. The developmen of methane production in childhood and adolescence. f Pediatr Gastroenterol Nutr 1985; 4: 575-9.

7 Bond JH, Engel RR, Levitt MD. Factors influencing pulmonary methane excretion in man. $\mathcal{f}$ Exp Med 1971; 133 $572-88$

8 Wolin MJ. Fermentation in the rumen and human large intestine. Science 1981; 213: 1463-8.

9 Thauer R. Limitation of microbial $\mathrm{H}_{2}$ formation via fermentation. In: Schlegel HG, Bornea J, eds. Microbial energy conversion. Göttingen: Erich Goltge KG, 1976: 201-4.

10 Christl SU, Murgatroyd PR, Gibson GR, Cummings JH. Production, metabolism, and excretion of hydrogen in the large intestine. Gastroenterology 1992; 102: 1269-77.

11 Gibson GR, Macfarlane GT, Cummings JH. Occurrence of sulphate reducing bacteria in human faeces and the relationship of dissimilatory sulphate reduction to methanogenesis in the large gut. $\mathcal{F}$ Appl Bacteriol 1988; 65: 103-11.

12 Gibson GR, Cummings JH, Macfarlane GT. Competition for hydrogen between sulphate-reducing bacteria and methanogenic bacteria from the human large intestine. $\mathcal{f} \mathrm{Appl}$ Bacteriol 1988; 65: 24l-7.

13 Florin THJ, Neale G, Gibson GR, Christl SU, Cummings JH The metabolism of dietary sulphate: absorption and excretion in man. Gut 1991; 32: 766-73.

14 Pomare EW, Branch WJ, Cummings JH. Carbohydrate fermentation in the human colon and its relation to acetate fermentation in the human colon and its relation to acetate
concentrations in venous blood. $\mathcal{F}$ Clin Invest 1985; 75: concentratic

15 Wolin MJ. Metabolic interactions among intestinal microorganisms. Am F Clin Nutr 1974; 27: 1320-8

6 Widdel F, Pfennig N. Studies on dissimilatory sulphate reducing bacteria that decompose fatty acids. I. Isolation of new sulphate reducing bacteria enriched with acetate from saline environments. Description of Desulphobacter postgatei gen nov., sp. nov. Arch Microbiol 1981; 129: 395400.

17 Allison C, Macfarlane GT. Effect of nitrate on methane production and fermentation by slurries of human faecal bacteria. F Gen Microbiol 1988; 134: 1398-405.

18 Cline JD. Spectrophotometric determination of hydrogen sulphide in natural waters. Limnology and Oceanography $1969 ; 14: 454-8$

19 Jorgensen $\mathrm{BB}$. A comparison of methods for the quantification of bacterial sulphate reduction in coastal marine sediments. I. Measurements with radiotracer techniques. Geomicrobiolf 1978; 1: 11-27.

20 Cummings JH, Wiggins HS. Transit through the gut measured by analysis of a single stool. Gut 1976;17: 219-23.

21 Bryant MP. Microbial methane production - theoretical aspects. F Anim Sci 1979; 48: 193-201.

22 Wolin MJ. Interactions between $\mathrm{H}_{2}$-producing and methaneproducing species. In: Schlegel HG, Gottschalk G, Pfennig $\mathrm{N}$, eds. Microbial formation and utilisation of gases. Göttiugeu: Goltze Press, 1976: 141-50.

23 Lorley DR, Dwyer DF, Klug MK. Kinetic analysis of competition between sulphate reducers and methanogens for hydrogen in sediments. Appl Environ Microbiol 1982; 43: 1373-9.

24 Kristjansson JK, Schönheit P, Thauer RK. Different $K_{S}$ values for hydrogen of methanogenic bacteria and sulphate reducing bacteria: an explanation for the apparent inhibition of methanogenesis by sulphate. Arch Microbiol 1982; 131: 278-82.

25 Cappenberg TE. Interrelations between sulphate-reducing and methane-producing bacteria in bottom deposits of a fresh water lake. II. Inhibition experiments. Antonie Van Leeuwenhoek 1974; 40: 297-306.

26 Macfarlane GT, Cummings JH. Comparison of fermentation reactions in different regions of the human colon. $\mathcal{F} \mathrm{Appl}$ Bacteriol 1992; 72: 57-64.

27 Florin THJ, Goretski S, Neale G, Cummings JH. Sulphate in foods and beverages. Br $\mathcal{F}$ Nutr (in press)

28 Gibson GR, Cummings JH, Macfarlane GT. Use of a threestage continuous culture system to study the effect of mucin on dissimilatory sulphate reduction and methanogenesis by mixed populations of gut bacteria. Appl Environ Microbiol $1988 ; 54: 2750-5$.

28 Bread and Flour Regulations. London: HMSO, 1984.

0 Hough JS, Briggs DE, Stevens R. Malting and brewing science. London: Chapman and Hall, 1978.

31 Wedzicha BL. Review: chemistry of sulphur dioxide in vegetable dehydration. Int $\mathcal{F}$ Food Sci Tech 1987; 22: 433-50. 